\title{
Penerapan Revisi Sumpah Dokter Terbaru oleh World Medical Association (WMA) di Indonesia
}

\author{
Agus Purwadianto ${ }^{\mathrm{I}, 2}$, Broto Wasisto ${ }^{\mathrm{I}, 3}, \mathrm{R}$ Sjamsuhidajat ${ }^{\mathrm{I}}$ \\ ${ }^{\mathrm{I}}$ Majelis Kehormatan Etik Kedokteran Pengurus Besar Ikatan Dokter Indonesia \\ ${ }^{2}$ Departemen Ilmu Kedokteran Forensik dan Medikolegal, Fakultas Kedokteran Universitas Indonesia/Rumah Sakit Cipto Mangunkusumo \\ ${ }^{3}$ Ikatan Konsultan Kesehatan Indonesia (Ikkesindo)
}

\author{
Kata Kunci \\ dokter, sumpah, revisi, World Medical \\ Association \\ Korespondensi \\ contact@ilmiah.id \\ Publikasi \\ (C) 2018 JEKI/ilmiah.id \\ DOI \\ Io.26880/jeki.v2it.9 \\ Tanggal masuk: 13 Februari 2018 \\ Tanggal ditelaah: 10 Maret 20I8 \\ Tanggal diterima: II Maret 2018 \\ Tanggal publikasi: I9 Maret 2018
}

\begin{abstract}
Abstrak World Medical Association (WMA) mengeluarkan revisi sumpah dokter terbaru dalam Deklarasi Geneva tahun 20I7. Sumpah dokter di Indonesia tercantum di KODEKI 2012 dan Peraturan Pemerintah (PP) No. 26 Tahun 1960. Sumpah disesuaikan dengan nilai dan keragaman agama di suatu negara. Beberapa revisi tersebut antara lain menghormati otonomi dan keluhuran pasien tanpa mempertimbangkan latar belakang pasien serta menghargai hubungan dengan guru, kolega, dan mahasiswa. Perubahan lainnya adalah menghilangkan kata "sejak konsepsi" pada butir menghormati kehidupan manusia. Butir tambahan adalah dokter akan menjaga kesehatan dirinya, menjalankan profesi sesuai praktis medis, dan akan membagi ilmu yang dimilikinya untuk kepentingan pasien. Untuk penerapannya di Indonesia, diperlukan persetujuan draft sumpah WMA yang disesuaikan dengan nilai di Indonesia, kemudian diterjemahkan oleh pihak yang dipilih PB IDI dan ditetapkan menjadi peraturan pemerintah.
\end{abstract}

\begin{abstract}
World Medical Association (WMA) has launced a revision of Declaration of Geneva in 2017. Doctor's Oath in Indonesia was based on Indonesian Medical Code of Ethics 2012 and government regulation (PP No. 26 Year I960). The oath is adjusted to Indonesia's diverse value and religion. Some revisions were to respect the autonomy and dignity of patients without considerations of patients backgrounds and to give respect and gratitude to teachers, colleagues, and students. Another modification was deletion of phrase "since conception" in the point of "I will maintain the utmost respect for human life", that doctor must attend to his own health, practice his profession accordance with good medical practice, and will share his medical knowledge for patient benefit. To be applied in Indonesia, the WMA Oath draft has to be adjusted with Indonesian value, translated, and then declared as government regulation.
\end{abstract}

\section{PENDAHULUAN}

Berdasarkan Kode Etik Kedokteran Indonesia tahun 2012 pasal 1, setiap dokter wajib menjunjung tinggi, menghayati, dan mengamalkan sumpah dan atau janji dokter. Dokter lulusan fakultas kedokteran di Indonesia melafalkannya di depan pimpinan fakultas, sementara dokter lulusan luar negeri atau asing melafalkan sumpah dokter di depan pemimpin IDI. Kalimat-kalimat dalam sumpah dokter telah mengalami perubahan dan penyempurnaan. Sumber pertama sumpah dokter yang diterapkan di Indonesia adalah Deklarasi Geneva 1948 dan terus disempurnakan hingga tahun 2012 di Muktamar IDI ke-28. ${ }^{1}$

Deklarasi Geneva merupakan sumpah yang diterapkan oleh World Medical Association (WMA) yang mencakup seluruh tugas dan prinsip etik profesi dokter, antara lain hubungan dokter-pasien, kerahasiaan medis, dan penghargaan terhadap guru dan kolega. Baru-baru ini, WMA membuat revisi terhadap Deklarasi Geneva pada tanggal 14 Oktober 2017..$^{2}$ 
Jika kedokteran Indonesia turut menggunakan revisi Deklarasi Geneva, perlu dipertimbangkan relevansi dan prinsip etik yang terdapat pada revisi tersebut.

\section{HASIL DAN PEMBAHASAN}

\section{Sumpah Dokter di Indonesia}

Sumpah sebagai moralitas hukum memiliki dua sifat, yakni promisoris dan asertoris. Sumpah promisoris adalah janji publik luas yang bersifat jangka panjang yang masuk ke ranah pelayanan medik. Sumpah asertoris adalah janji public yang terbatas dan berjangka pendek. Jika masuk ke pengadilan, masuk ke ranah medikolegal. Sumpah dokter merupakan sumpah yang bersifat promisoris. Di Indonesia, terdapat dua jenis sumpah yang dipakai dalam pelantikan dokter, yakni berdasarkan Kode Etik Kedokteran Indonesia 2012 dan PP 26 tahun 1960 tentang Lafal Sumpah Dokter. Isi keduanya kurang lebih sama.

Peraturan pemerintah adalah peneguhan sumpah untuk kepentingan publik. Peraturan pemerintah tidak memiliki sanksi hukum. Dokter yang melanggar pasal 1, akan melanggar etik, KODEKI, dan sumpah. Di era defensive medicine, pelanggaran terdapat sumpah membuat dokter melanggar etik, sumpah, dan hukum.

Sumpah kedokteran diucapkan sebanyak satu kali kemudian akan mendapat sertifikat yang akan berlaku universal. Sumpah diucapkan di hadapan dekan suatu fakultas kedokteran didampingi pemuka agama sebagai simbol bahwa ucapan oleh calon dokter didengar oleh Tuhan sehingga menjadi suatu dosa jika dilanggar. Sumpah yang diucapkan oleh dokter berbeda dengan sumpah yang diucapkan di pengadilan karena sumpah dokter berhubungan dengan sesuatu yang akan dijalankan.

Sumpah di Indonesia dimuat di dalam Peraturan Pemerintah dan KODEKI (yang berasal dari kesepakatan dokter) sehingga pelanggaran yang dilakukan masuk ke dalam pelanggaran etik dan sumpah sesuai kebijakan majelis. Pelanggaran etik membuat seorang dokter dapat menjadi dokter lagi setelah hukuman selesai dijalankan. Sementara itu, pelanggaran sumpah membuatnya tidak dapat menjadi seorang dokter lagi, serta dapat masuk ke ranah pidana jika ada undang-undang yang mengaturnya. Akan tetapi, belum ada ketentuan hukuman mengenai pelanggaran sumpah. Masalah lainnya adalah Indonesia merupakan negara dengan bermacam agama sehingga untuk penerapannya apakah perlu mengakomodir semua agama?

\section{Deklarasi Geneva}

World Medical Association (WMA) menggunakan Deklarasi Geneva 1948 sebagai dasar sumpah dokternya. Deklarasi ini diyakini sebagai Sumpah Hipokrates modern yang diucapkan dokter dalam menjalankan profesinya sesuai komitmen moral. ${ }^{3}$

Deklarasi Geneva merupakan salah satu sumpah selain Sumpah Hipokrates yang banyak digunakan dalam profesi dokter. Di setiap negara, sumpah disesuaikan dengan kondisi negaranya. Sumpah dokter Indonesia, tercantum dalam Kode Etik Kedokteran Indonesia, menggunakan Deklarasi Geneva tahun 1948 sebagai sumber pertama. Sumpah dokter Indonesia terus mengalami pembaharuan kalimat yang disesuaikan dengan kebutuhan.,

Selain sebagai sumpah, Deklarasi Geneva juga digunakan sebagai kode etik profesi kedokteran. Selama 67 tahun, Deklarasi Geneva sudah mengalami beberapa perubahan minor. Dibandingkan dengan Sumpah Hipokrates, Deklarasi Geneva hanya menyinggung penghormatan murid terhadap gurunya. Sementara itu, Sumpah Hipokrates menyinggung adanya hubungan timbal balik guru dan murid dalam proses pendidikan seorang dokter. Menghargai pertimbangan pasien, suatu isu yang sudah berkembang saat ini, juga belum disebutkan dalam Deklarasi Geneva. $^{3}$

Perubahan kehidupan kedokteran terus terjadi seiring perubahan kondisi demografik dan sosioekonomi masyarakat serta perkembangan dunia medis dan teknologi. Perubahan-perubahan yang terjadi harus mempertimbangkan tujuan atau akibat yang lebih baik disertai prinsip moral. Prinsip moral tersebut menjadi jangkar penting untuk tetap 
dimasukkan dalam sumpah dokter. ${ }^{3}$

\section{Perubahan yang Terjadi pada Revisi Declaraton of Geneva}

Revisi terhadap Deklarasi Geneva disetujui oleh negara yang hadir. Akan tetapi, PB IDI tidak mengirimkan perwakilan sehingga belum ada persetujuan apakah akan mengikuti revisi tersebut. (Tabel 1)

Perubahan Deklarasi Geneva dibuat oleh seluruh negara anggota dengan memperhatikan latar belakang, benua, budaya, dan agama yang beragam. Pertimbangan dalam revisi disesuaikan dengan faktor lingkungan yang akan atau telah terjadi dengan tetap mempertahankan prinsip dasar moral untuk mempertahankan semaksimal mungkin norma universal. ${ }^{3}$

Prinsip etik yang terdapat pada lafal sumpah tersebut adalah: kerahasiaan, menghargai kolega dan profesi, menghargai kehidupan manusia, acuan standar untuk perilaku pribadi, menolak diskriminasi, menghargai pasien, beneficence, kemanusiaan, menghargai otonomi, kesetaraan, dan kesehatan, menghargai guru, non-maleficence, menghargai hak asasi manusia, keadilan, dan menghargai murid. ${ }^{4}$

Perubahan yang terjadi pada Deklarasi Geneva 2017 adalah dicantumkannya autonomy dan dignity sebagai butir "I will respect the autonomy and dignity of my patient" sebagai simbol profesionalisme, yang diletakkan di bagian awal dan menunjukkan bahwa hak pasien adalah yang utama, untuk kemudian diikuti dengan kewajiban profesi. Dalam KODEKI, sumpah dokter mengenai penghargaan hak pasien tercantum dalam poin keempat dan keenam., ${ }^{1,2}$

Selain itu, dokter juga diharapkan dapat menghormati orientasi seksual pasien yang terdapat dalam butir "I will not permit considerations of age, disease or disability, creed, ethnic origin, gender, nationality, political affiliation, race, sexual orientation, social standing, or any other factor to intervene between my duty and my patient"

Butir lainnya yang diubah adalah "My colleagues will be my sisters and brothers," menjadi "I will give to my teachers, colleagues, and students the respect and gratitude that is their due". Di butir ini, konsep kesejawatan bergeser. Butir ini menekankan bahwa dokter adalah insan atau makhluk yang bermartabat yang menghormati hubungan dengan kolega, guru, dan mahasiswa. Butir yang menjaga hubungan dokter dan mahasiswanya ini dimaksudkan supaya terjadi transfer ilmu pengetahuan terhadap generasi selanjutnya (andragogi) dan mencegah bullying. Pada sumpah dokter KODEKI poin kesembilan dan kesepuluh, terdapat sumpah mengenai hubungan dokter dengan kolega dan murid terhadap guru. Akan tetapi, tidak tercantum sumpah mengenai hubungan guru terhadap murid. ${ }^{1,2}$

Butir "I will maintain the utmost respect for human life" menghilangkan "respect for human life, from the time of conception". Penghapusan ini menimbulkan masalah akibat kemajuan teknologi (IVF dan stem cell) yang dapat bertentangan dengan tanda kehidupan dimulai (pada embrionik stem cell). Oleh sebab itu, diperlukan kesepakatan sejak kapan kehidupan dimulai dengan mempertimbangkan keragaman agama dan kepercayaan di Indonesia tentang waktu dimulainya kehidupan.

Butir baru "I will practise my profession with conscience and dignity" dikuatkan dengan menambahkan "and in accordance with good medical practice" untuk meningkatkan standar etik dan profesionalisme dokter sebagai janji publik. Poin ini telah tercantum pada sumpah dokter nomor 2 dan 7.,2

Terdapat butir tambahan, yakni "I will attend to my own health, well-being, and abilities in order to provide care of the highest standard. Pada butir ini, dokter diharapkan harus tetap menjaga dan mempedulikan kesehatannya sendiri. Semua pemangku kepentingan akan dilibatkan akibat adanya butir ini untuk mempertimbangkan beban kerja, stress pekerjaan, dan dampak yang potensial mengakibatkan terjadinya faktor risiko gangguan kesehatan dan kesejahteran dokter. Begitu strategisnya kemampuan publik dokter, menempatkan dokter untuk bertanggung jawab pula atas dirinya ${ }^{1,2}$

Butir baru lainnya adalah "I will share my medical knowledge for the benefit of the patient and the advancement of healthcare". Selain itu, terdapat pernyataan penguatan berupa "I will foster the honour and noble traditions of the medical profession" 


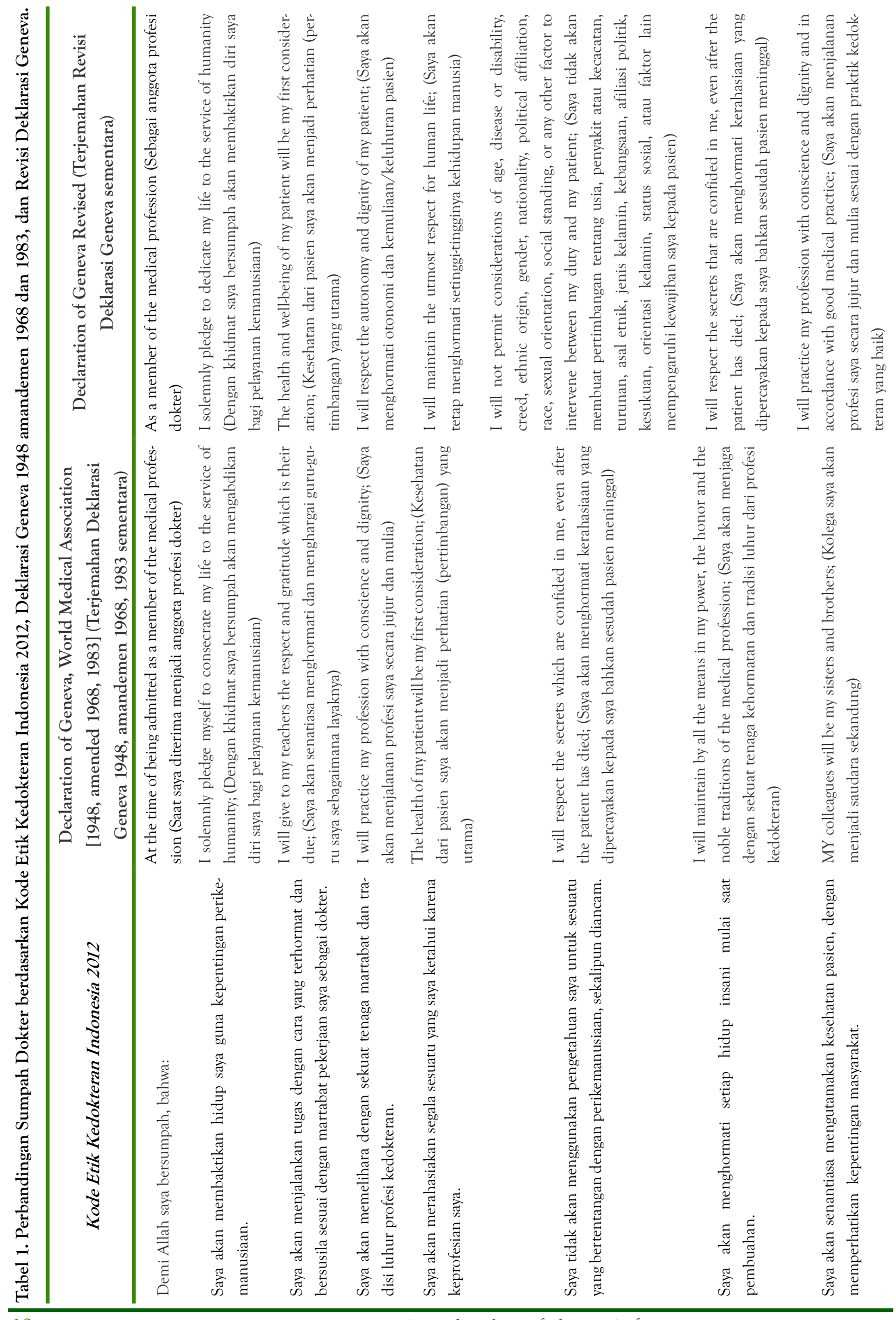




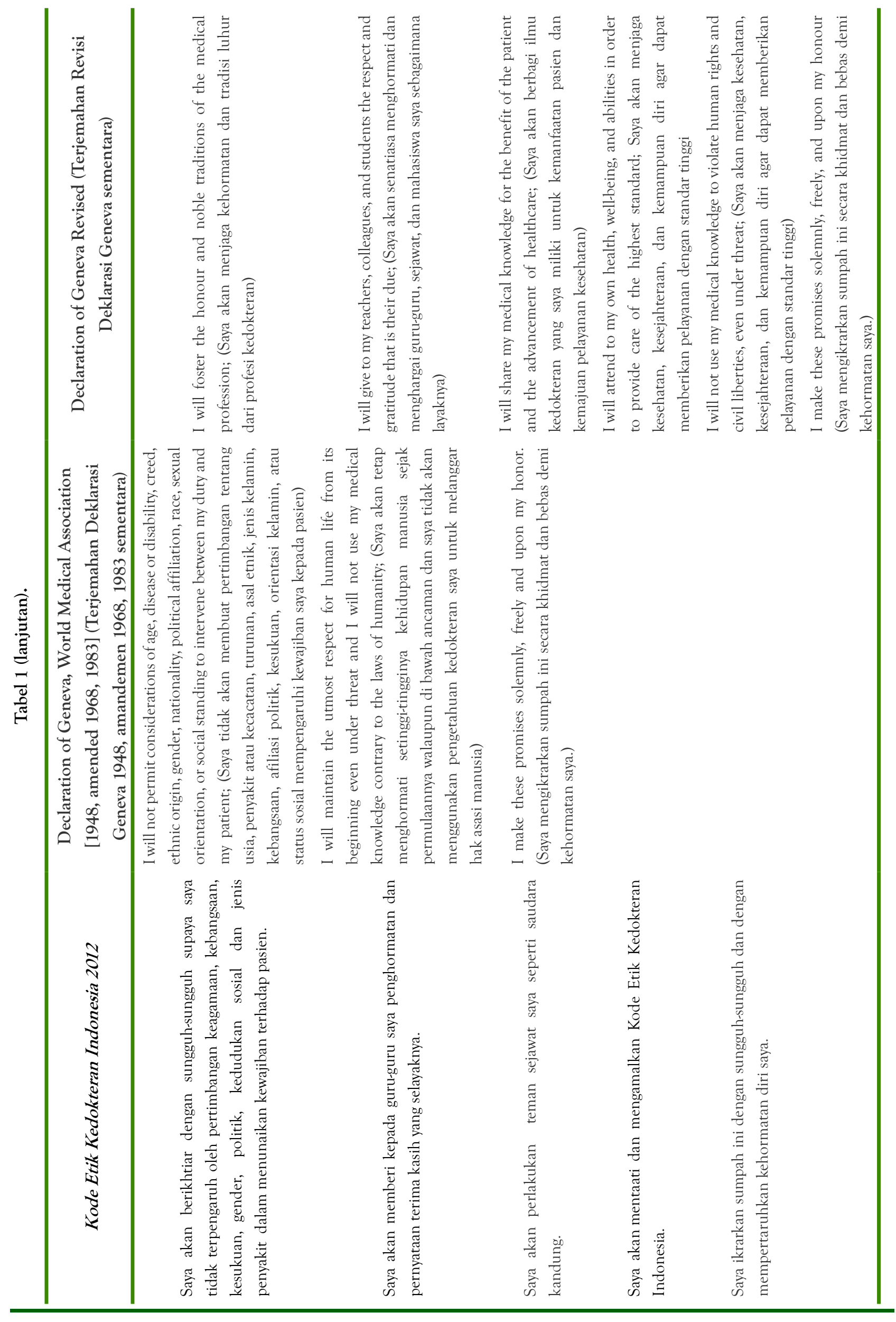




\section{Penerapan Deklarasi Geneva yang Direvisi di Indonesia}

Deklarasi Geneva dibuat untuk memperbaharui Sumpah Hipokrates. Revisi yang dilakukan pada Deklarasi Geneva mempertimbangkan nilai otonomi. ${ }^{\text {e }}$ Pada penelitian Rheinsberg, Deklarasi Geneva diterapkan oleh pendidikan kedokteran, pembuatan peraturan, dan menteri kesehatan. Pada penelitian tersebut, dikatakan bahwa penggunaan teks sumpah selain Deklarasi Geneva dapat dilakukan karena adanya perbedaan standar etik dokter di setiap negara ditambah dengan adanya globalisasi yang membuat perbedaan latar belakang dan budaya menjadi semakin berkembang. Prinsip utamanya disesuaikan dengan nilai moral, salah satunya adalah tidak diskriminasi terhadap budaya dan agama. ${ }^{4,5}$

Prinsip moral pada Deklarasi Geneva yang direvisi adalah menghormati kolega dan profesi, menghargai otonomi pasien, menghargai kehidupan, dan menolak diskriminasi, yang telah terdapat pada berbagai macam sumpah dokter yang sudah disesuaikan dengan kondisi saat ini. ${ }^{4}$

Untuk penerapannya di Indonesia, perlu disesuaikan dengan nilai dan kepercayaan yang beragam di Indonesia. MKEK perlu melakukan pembuatan draft terjemahan dengan melihat adanya nilai-nilai yang baru atau berubah yang disesuaikan dengan nilai yang dianut. Kemudian, perlu dilakukan penerjemahan oleh pihak yang dipilih oleh PB IDI, lalu diangkat menjadi peraturan pemerintah melalui Menteri Kesehatan dan kabinet.

\section{KESIMPULAN}

Perubahan pada Deklarasi Geneva dapat menjadi masukan untuk memperbaharui Sumpah Dokter Indonesia setelah disesuaikan dengan nilai dan agama di Indonesia. Penerapan Deklarasi Geneva yang direvisi memerlukan persetujuan akan nilai yang akan diambil, kemudian diterjemahkan oleh pihak yang ditentukan PB IDI dan diatur dalam peraturan pemerintah.

\section{KONFLIK KEPENTINGAN}

Tidak ada konflik kepentingan

\section{REFERENSI}

1. Pengurus Besar Ikatan Dokter Indonesia. Kode Etik Kedokteran Indonesia. 2012. Pasal 1.

2. Parsa-Parsi RW. The revised declaration of Geneva: A modern-day physician's pledge. JAMA 2017;318(20):1971-2. doi: 10.1001/ jama.2017.16230.

3. Wiesing U, Parsa-Parsi R. The World Medical Association launches a revision of the Declaration of Geneva. Bioethics. 2016 Mar 1;30(3): 140. doi: 10.1111/bioe.12256.

4. Rheinsberg Z, Parsa R, Kloiber O, Wiesing U. Medical oath: Use and relevance of the Declaration of Geneva. A survey of member organizations of the World Medical Association. Med Health Care and Philos 2017. doi: 10.1007/ s11019-017-9794-x.

5. Kuroyanagi T. Historical transition in medical ethics: Challenges of the World Medical Association. JMAJ 2013;56(4):220-6. 